\title{
PENGARUH GREEN PRODUCT (MINUMAN RAMAH LINGKUNGAN), GREEN ADVERTISING, DAN KEPEDULIAN LINGKUNGAN TERHADAP GREEN TRUST DAN IMPLIKASI TERHADAP MINAT BELI
}

\section{The Effect of Green Product (Enviromental Friendly Drink), Green Advertising, and Environmental Concern to Green Trust and Implications on Purchase Intention}

\author{
Endah Rahayu Lestari*, Hanifa Kirana Putri, Cornelia Anindita, Maria Bernadhetta Laksmiari \\ Jurusan Teknologi Industri Pertanian - Fakultas Teknologi Pertanian -Universitas Brawijaya \\ Jl. Veteran - Malang 65145 \\ *Penulis Korespondensi, email: endahlestari24@ub.ac.id
}

Disubmit: 5 Desember 2019 Direvisi: 19 Februari 2020 Diterima: 27 Februari 2020

\begin{abstract}
ABSTRAK
Pertumbuhan industri minuman non-alcoholic ready to drink (RTD) di Indonesia kian meningkat seiring dengan perubahan gaya hidup masyarakat. Berkaitan dengan maraknya isu lingkungan akibat kegiatan industri yang tidak bertanggung jawab, beberapa perusahaan minuman RTD berupaya menerapkan strategi green marketing yang bertujuan untuk meningkatkan minat beli konsumen terhadap produk hijau. Kerangka pikir penelitian ini menggunakan Theory of Reasoned Action, yang menjelaskan bahwa minat seseorang terbentuk dari sikap dan norma subjektif. Tujuan penelitian ini adalah untuk menguji secara empirik pengaruh green product, green advertising, dan kepedulian lingkungan, terhadap green trust dan selanjutnya menguji hubungan antara green trust terhadap minat beli produk hijau. Penelitian ini menggunakan pemodelan struktural dan pengolahan data menggunakan WarpPLS 4.0 (Partial Least Square). Penelitian dilaksanakan di Kota Malang. Penentuan responden menggunakan teknik purposive sampling, sebanyak 280 orang. Hasil penelitian menunjukkan bahwa green product, green advertising, dan kepedulian lingkungan masing-masing berpengaruh positif signifikan terhadap green trust. Selanjutnya terdapat hubungan positif signifikan antara green trust dengan minat beli produk hijau.
\end{abstract}

Kata kunci: Green Advertising; Green Product; Green Trust; Minat Beli; Kepedulian Lingkungan;

\begin{abstract}
The growth of the non-alcoholic ready to drink (RTD) beverage industry in Indonesia is increasing along with changes in people's lifestyles. Regarding the environmental issues due to irresponsible industrial activities, some RTD beverage companies are trying to implement a green marketing strategy aimed at increasing consumer buying interest in green products. This research framework uses Theory of Reasoned Action, which explains that a person's interests are formed from attitudes and subjective norms. The purpose of this study is to empirically examine the effect of green products, green advertising, and environmental concern on green trusts, then analyze the relationship between green trusts and purchase intention of green products. This study uses structural modeling with the WarpPLS 4.0 (Partial Least Square) method for data analysis. The study was conducted in Malang and the selection of 280 respondents used purposive sampling techniques. The results showed that green products, green advertising, and environmental concern each had a significant positive effect on green trust. Furthermore, there is a positive relationship between green trust and purchase intention.
\end{abstract}

Keywords: Green Advertising; Green Product; Green Trust; Environmental Concern; Purchase Intention 


\section{PENDAHULUAN}

Permasalahan lingkungan sebagai akibat dari aktivitas manusia dan kegiatan industri manufaktur yang tidak bertanggung jawab, menjadi perbincangan di seluruh dunia hingga saat ini. Permasalahan lingkungan yang sering diperbincangkan meliputi pemanasan global, pencemaran air laut, deforestasi hutan, kelangkaan air bersih, serta menurunnya keanekaragaman hayati (Chen, 2011). Kondisi lingkungan yang kian memburuk memotivasi para pelaku bisnis untuk lebih memperhatikan aspek ekologis dalam menjalankan usahanya, yaitu dengan menciptakan produk ramah lingkungan atau biasa disebut sebagai produk hijau atau green product (Irfan dan Khiriyah, 2013). Green product dapat dideskripsikan sebagai produk yang aman bagi kesehatan (Sdrolia dan Zarotiadis, 2019), kemasannya mencantumkan logo eco-label (Jørgensen dan Moen, 2015) yang memberikan informasi bahwa kemasan produk bersifat ramah lingkungan (Ihemezie et al., 2018). Terdapat beberapa contoh produk hijau yang biasa dijumpai dalam kehidupan sehari-hari, diantaranya makanan organik, minuman ready to drink (RTD), lampu hemat energi, kendaraan hemat bahan bakar, dan lain-lain (Chen dan Chai, 2010). Green product memiliki kinerja lingkungan yang lebih baik dibandingkan dengan produk konvensional lainnya (Albino, et al., 2009).

Berbagai upaya strategis dalam proses produksi maupun kegiatan pemasaran dilakukan perusahaan untuk menciptakan produk hijau yang dikenal sebagai green marketing (Grewal dan Levy, 2010). Salah satu tujuan green marketing yaitu untuk menciptakan perilaku konsumsi ramah lingkungan di masyarakat, contohnya dengan membeli produk hijau. Manfaat green marketing bagi konsumen ialah mendapatkan produk yang berkualitas bagi kesehatan maupun bagi lingkungannya (Utami et al 2014). Terwujudnya perilaku konsumsi ramah lingkungan diharapkan dapat meminimalkan kerusakan lingkungan, sehingga mampu meningkatkan kesejahteraan masyarakat. Tujuan tersebut akan tercapai, apabila perusahaan mampu memahami faktor-faktor yang mendorong perilaku konsumsi ramah lingkungan (Wu dan Chen, 2014). Theory of
Reasoned Action menyatakan bahwa minat seseorang ter-bentuk dari sikap dan norma subjektif (Hennessy, 2012). Lebih lanjut Sreen et al., (2017) mengemukakan bahwa sikap meru-pakan prediktor minat yang paling akurat. Hal tersebut didukung oleh hasil studi yang membuktikan bahwa makin positif sikap konsumen terhadap produk hijau, makin tinggi minat untuk membeli produk tersebut (Suki, 2013).

Pertumbuhan industri minuman nonalcoholic ready to drink (RTD) di Indonesia kian meningkat dari tahun ke tahun (Poeradisastra, 2011). Perubahan gaya hidup masyarakat mengakibatkan minuman RTD menjadi produk yang sangat diminati, selain untuk kepraktisan juga untuk memperoleh manfaat yang diberikan oleh produk tersebut. Minuman RTD yang beredar di Indonesia terbagi menjadi beberapa kategori, diantaranya adalah air minum dalam kemasan, teh siap minum, sari buah, susu, kopi, minuman berkarbonasi, minuman isotonik, dan minuman fungsional. Berkaitan dengan tingkat konsumsi masyarakat Indonesia terhadap minuman RTD yang diperkirakan akan terus meningkat, maka banyak perusahaan berupaya memproduksi minuman RTD yang dapat memenuhi kebutuhan kon-sumen, menguntungkan perusahaan, serta aman bagi lingkungan. Komitmen dan kredibilitas perusahaan untuk menghasilkan produk hijau (green product) dibandingkan produk lainnya akan berpengaruh dalam meningkatkan kepercayaan dan keputusan pembelian konsumen (Rasaputr dan Choon-Yin, 2015).

Upaya produsen menawarkan green product kepada masyarakat didukung dengan promosi yang dikenal dengan green advertising. Menurut d'Souza et al. (2006); serta Testa et el., (2013) salah satu strategi dilakukan perusahaan untuk mempromosikan produknya yaitu dengan mencantumkan eco-label pada kemasan. Selain itu, beberapa perusahaan menggunakan tagline iklan televisi agar menarik perhatian konsumen untuk peduli lingkungan, seperti produk minuman Ades dengan tagline "pilih, minum, remukkan". Produk minuman Aqua dalam iklan televisi mengklaim bahwa produknya berasal dari sumber mata air pilihan yang terjaga kualitasnya. Melalui website resminya, Aqua menyampaikan visi bisnisnya yaitu memajukan ekonomi sekaligus berkontribusi 
pada sosial dan lingkungan. Produk minuman lain seperti susu indomilk, susu ultramilk, teh kotak, susu greenfield, buavita dan lain sebagainya juga melakukan green advertising dengan menggunakan kemasan paperboard yang bersifat ramah lingkungan. Produk-produk seperti teh gelas, teh botol sosro, coca-cola dan lainnya juga melakukan green advertising dengan mengadakan event (acara-acara) yang tujuannya memberi edukasi kepada masyarakat pentingnya menjaga kelestarian lingkungan. Hal tersebut disampaikan melalui website resmi, artikel media online dan media cetak. Green advertising juga dapat dilihat melalui promosi go green (Ruanguttamanun, 2014), motivasi untuk peduli lingkungan (Mkik et al., 2017), dan adanya tindakan nyata pelestarian lingkungan (Richards, 2013).

Green product dan green advertising tidak hanya sebagai upaya pemenuhan kebutuhan dan kepedulian konsumen terhadap lingkungan, tetapi juga untuk menumbuhkan kepercayaan atau keyakinan terhadap manfaat mengkonsumsi produk hijau. Kepercayaan merupakan keyakinan bahwa produk dapat diandalkan karena memiliki harapan positif serta memunculkan komitmen (Ling, et al., 2011). Sikap percaya akan memberikan dorongan bagi konsumen untuk melakukan keputusan pembelian pada produk yang diyakini sebagai produk ramah lingkungan dan aman dikonsumsi atau disebut sebagai green trust (Astini, 2016; Mei et al., 2012), sehingga pada akhirnya konsu-men akan lebih memilih minuman ramah lingkungan dibandingkan produk minuman yang tidak ramah lingkungan (Halim dan Kempa, 2016; Suki, 2013).

Kepedulian lingkungan dan pengetahuan tentang atribut produk ramah lingkungan seperti pencatuman eco-label pada produk merupakan faktor utama yang dapat membentuk sikap positif dalam mempengaruhi perilaku pembelian produk hijau (Aman et al., 2012). Kepedulian lingkungan dapat diartikan sebagai upaya-upaya yang dilakukan seseorang untuk ikut serta dalam melestarikan lingkungan (Junaedi, 2008). Kesadaran yang dimiliki konsumen terhadap apa yang sedang terjadi di lingkungannya akan membuat konsumen menyadari bahwa ia membutuhkan produk yang ramah lingkungan, sehingga meningkatkan kepedulian kelestarian lingkungan, tertarik terhadap produk ramah lingkungan, dan terbiasa mengonsumsi minuman ramah lingkungan (Suki, 2013). Dari uraian di atas, maka tujuan penelitian ini untuk menguji secara empiris pengaruh green product, green advertising, serta kepedulian lingkungan terhadap green trust dan implikasinya terhadap minat beli produk hijau.

\section{Pengembangan Hipotesis \\ Green Product dengan Green Trust}

Istilah produk hijau di Indonesia lebih dikenal sebagai produk ekologi atau produk ramah lingkungan. Miranti (2012) mendefinisikan produk hijau sebagai produk yang dapat mengurangi kerusakan lingkung-an karena tidak atau sedikit mengandung material yang berbahaya bagi lingkungan, hemat energi dalam proses produksi dan konsumsinya, serta tidak mencemari udara, air, dan tanah. Produk hijau juga dapat dideskripsikan sebagai produk yang tidak berbahaya bagi manusia dan lingkungannya dan limbahnya bisa didaur ulang. Selain itu, bahan kemasan menggunakan hasil penerbangan hutan yang dikelola secara bertanggung jawab (Widmer dan Frick, 2007).

Pengetahuan konsumen mengenai produk hijau menumbuhkan kesadaran terhadap keberadaan produk tersebut (Suki, 2013). Pengetahuan tentang lingkungan, green product, maupun eco-label merupakan ante-seden dari sikap percaya konsumen terhadap produk ramah lingkungan. Hal ini telah dibuktikan Taufique, Siwar, Chamhuri, dan Sarah (2016) dalam risetnya di Malaysia yaitu makin tinggi pengetahuan konsumen mengenai lingkungan dan eco-label akan meningkatkan sikap positif terhadap lingkungan, sehingga mendorong perilaku pembelian produk ramah lingkungan. Pengukuran green trust didasarkan pada kinerja produk terhadap lingkungan, produk dapat dipercaya, komitmen perusahaan terhadap kelestarian lingkungan (Chen dan Chai, 2010).

Alshura dan Zabadi (2016) mengungkapkan bahwa sikap percaya terhadap produk hijau konsumen di Jordania ditentukan signifikan oleh intensitas penggunaan green product. Atkinson dan Rosenthal (2014) menambahkan bahwa pencantuman ecolabel pada produk akan memunculkan rasa 
percaya konsumen pada produk hijau. Hal yang sama juga dinyatakan oleh Cahyani dan Wardana (2017) dalam penelitiannya di Denpasar bahwa persepsi positif terhadap green produk mengakibatkan sikap percaya terhadap produk hijau dan selanjutnya meningkatkan minat pembelian produk hijau ulang. Maka:

H1. Green product (minuman ramah lingkungan) berpengaruh positif terhadap green trust

\section{Green advertising dengan Green Trust}

Green advertising dapat didefinisikan sebagai iklan yang mempromosikan produk hijau untuk menarik minat konsumen untuk memenuhi keinginan dan kebutuhan mereka terhadap produk hijau (Testa et al., 2013). Green advertising menjadi popular sejak permintaan produk ramah lingkungan meningkat drastis. Umumnya, green advertising menampilkan eco-label, warna hijau, pemandangan alam, dan kepedulian terhadap kelestarian lingkungan dan biasanya menonjolkan aspek adanya upaya perusahaan untuk mengurangi kerusakan lingkungan melalui gaya hidup "hijau" dan peningkatan perhatian lingkungan oleh perusahaan (Priyantika dan Wardana, 2015). Green advertising yang disampaikan secara tepat diharapkan akan memberikan kesan tersendiri dan melekat di benak konsumen sehingga dapat mempengaruhi keputusan pembelian.

Hubungan antara green advertising dengan sikap terhadap produk hijau dikaji Batool dan Rizwana (2016) di Universitas Islamia Bahawalpur Pakistan, mengungkapkan bahwa mahasiswa merespon positif terhadap green advertising yang dilakukan oleh perusahaan. Penelitian Gunarso dan Kusumawati (2017) juga menyimpulkan bahwa green advertising berpengaruh terhadap sikap percaya (green trust) terhadap produk hijau. Green advertising mampu menarik perhatian konsumen karena mampu menunjukkan kekhawatiran dan kepedulian terhadap isu lingkungan, sehingga konsumen merasa yakin terhadap produk ramah lingkungan (Hassan dan Valenzuela, 2016). Dengan demikian,
H2. Green advertising berpengaruh positif terhadap green trust

\section{Kepedulian Lingkungan dengan Green Trust}

Kepedulian lingkungan dapat diartikan sebagai kesadaran atau wawasan seseorang bahwa keadaan alam terancam oleh pemakaian sumber daya alam yang berlebihan dan polusi yang ditimbulkan oleh aktivitas manusia (Kalafatis, et al., 2013). Menurut Said et al. (2003) kepedulian lingkungan sebagai perhatian dan kontribusi yang diberikan seseorang terhadap kelestarian lingkungan. Chan dan Lau (2000) menegaskan bahwa kepedulian lingkungan mengacu pada tingkat emosional seseorang terkait dengan masalah lingkungan. Diamantopoulos et al. (2003) menjelaskan bahwa kepedulian lingkungan yang dimiliki seseorang terdiri dari tiga dimensi, yaitu pengetahuan mengenai isu lingkungan, kesadaran terhadap lingkungan dan sensitifitas terhadap lingkungan.

Aman et al. (2012) membuktikan bahwa kepedulian lingkungan berpengaruh signifikan terhadap sikap percaya konsumen terhadap produk hijau. Hasil penelitian ini juga membuktikan bahwa sikap terhadap green product memediasi secara parsial hubungan antara kepedulian lingkungan dengan minat beli produk hijau. Pengaruh kepedulian lingkungan terhadap sikap percaya terhadap produk hijau juga telah dikaji oleh Khaola et al. (2014) di Lesotho pada konsumsi makanan organik, menyimpulkan bahwa kepedulian lingkungan berpengaruh positif terhadap sikap konsumen, artinya makin tinggi kepedulian lingkungan maka keyakinjan konsumen terhadap produk hijau juga makin tinggi. Sehingga,

H3. Kepedulian lingkungan berpengaruh positif terhadap green trust

\section{Green Trust dengan Minat Beli}

Theory of Reasoned Action menjelaskan bahwa minat beli merupakan faktor pembentuk perilaku konsumen. Simamora (2004) mendefinisikan minat beli sebagai keinginan untuk membeli suatu produk karena adanya pengaruh eksternal maupun internal, dimana sebelumnya dilakukan evaluasi terhadap produk yang akan dibeli. 
Minat merupakan sesuatu yang bersifat pribadi dan berhubungan dengan sikap. Setiap individu yang berminat ter-hadap suatu objek akan memiliki do-rongan untuk melakukan serangkaian ting-kah laku guna mendapatkan objek tersebut, termasuk dengan cara membayar atau menukar dengan uang (Gbadamosi, 2016).

Penelitian Sreen et al. (2017) menganalisis hubungan antara sikap konsumen terhadap minat beli produk hijau, menjelaskan bahwa sikap merupkan predictor kuat terhadap minat beli. Penelitian yang sama oleh Suki (2016) menyimpulkan sikap percaya konsumen yang makin tinggi terhadap produk hijau berdampak terhadap peningkatan minat beli, karena produk hijau memiliki citra baik di mata konsumen sehingga makin termotivasi untuk membeli produk tersebut. Selanjutnya Yadav dan Pathak (2017) mencoba memahami faktorfaktor yang mem-pengaruhi perilaku pembelian produk hijau di India dengan menggunakan Theory of Planned Behavior (TPB) sebagai kerangka berpikir. Hasil penelitian menunjukkan bahwa makin positif keyakinan konsumen terhadap produk hijau maka minat untuk membeli produk tersebut makin tinggi. Kemudian dijelaskan pula bahwa minat beli secara signifikan mempengaruhi perilaku pembelian aktual. Maka,

H4. Green trust berpengaruh positif terhadap minat beli produk hijau

\section{METODE}

Penelitian ini dilakukan di Kota Malang menggunakan teknik purposive sampling sejumlah 280 responden dengan ketentuan telah membeli minuman ramah lingkungan minimal 2 kali dalam 3 bulan terakhir pada saat pengambilan data. Pengumpulan data menggunakan kuesioner terstrukur terdiri 15 item dengan skala Likert lima point mulai dari 1 "sangat tidak setuju" hingga 5 "sangat setuju".

Menurut Ferdinand (2006) ukuran sampel ditentukan berdasarkan jumlah indikator penelitian, dikalikan 5 - 10. Maka dari itu jumlah sampel penelitian ini paling sedikit (minimal) 150 orang. Pengujian reliabilitas data menggunakan software SPSS 19.0 dan pengujian data menggunakan software WarpPLS 4.0. Variabel penelitian beserta sumber pustaka tertera pada Tabel 1.

Tabel 1. Varibel penelitian dan sumber pustaka

\begin{tabular}{ll}
\hline Variabel & Sumber pustaka \\
\hline $\begin{array}{l}\text { Green } \\
\text { product }\end{array}$ & $\begin{array}{l}\text { Sdrolia dan Zarotiadis, 2019; } \\
\text { Jorgensen dan Moen, 2015; } \\
\text { Ihemezie et al., 2018 }\end{array}$ \\
\hline Green & Muslim dan Indriani, 2014; \\
Advertising & $\begin{array}{l}\text { Richards, 2013; Ruangutta- } \\
\text { manun, 2014 }\end{array}$ \\
\hline Kepedulian & Nguyen dan Du, 2010; \\
lingkungan & Seyrek dan Gul, 2017 \\
\hline Green Trust & Sreen et al., 2017; Muslim \\
& dan Indriani, 2014 \\
\hline Minat beli & Sreen et al., 2017; Kabadayi et \\
& al., 2015 \\
\hline
\end{tabular}

\section{HASIL DAN PEMBAHASAN}

Hasil analisis data meliputi reliabilitas data, loading factor, dan pengujian hipotesis. Pengujian reliabilitas data menggunakan acuan nilai Cronbach Alpha dengan pedoman $>0,6$. Hasil pengujian reliabilitas data menunjukkan bahwa green product, green advertising, kepedulian lingkungan, green trust, dan minat beli produk hijau berturutturut memiliki nilai Cronbach Alpha 0,701; 0,$769 ; 0,789 ; 0,783$; dan 0,670 , artinya bahwa kuesioner memiliki kemampuan untuk memberikan hasil pengukuran yang konsisten. Evaluasi Goodness of fit model pengukuran (outer model) meliputi validitas konvergen, validitas diskriminan, dan composite reliability. Hasil pengukuran menunjukkan bahwa seluruh konstruk pada model pengukuran telah memenuhi kriteria validitas diskriminan dengan nilai loading factor $>0,5$ dan nilai composite reliability $>0,7$. Secara ringkas hasil evaluasi model pengkuran dirangkum dalam Tabel 2. 
Tabel 2. Hasil uji realibilitas data

\begin{tabular}{lccc}
\hline Variabel/konstruk & $\begin{array}{c}\text { Loading } \\
\text { factor }\end{array}$ & $\begin{array}{c}\text { Cronbach } \\
\text { Alpha }\end{array}$ & $\begin{array}{c}\text { Composite } \\
\text { reliability }\end{array}$ \\
\hline Green Product & & 0,701 & 0,817 \\
- Kualitas produk & 0,784 & & \\
- Aman bagi kesehatan & 0,694 & & \\
- Pencantuman eco-label dalam kemasan & 0,702 & & \\
- Penggunaan bahan kemasan & 0,723 & & 0,867 \\
\hline Green advertising & 0,822 & & \\
- Citra produk & 0,811 & & \\
- Himbauan going green & 0,848 & & 0,881 \\
- Kelestarian lingkungan & & 0,798 & \\
\hline Kepedulian Lingkungan & 0,823 & & \\
- Perhatian pada isu-isu lingkungan & 0,866 & & \\
- Perhatian terhadap keberadaan produk hijau & 0,842 & & \\
- Intensitas mencari informasi produk hijau & & 0,783 & \\
\hline Green Trust & 0,767 & & \\
- Aman bagi lingkungan & 0,858 & & 0,800 \\
- Solusi perlindungan lingkungan & 0,779 & & \\
- Dampak negatif terhadap lingkungan & & 0,670 & \\
\hline Minat beli & 0,753 & & \\
- Lebih tertarik pada produk hijau & 0,754 & & \\
- Menghindari produk selain produk hijau & &
\end{tabular}

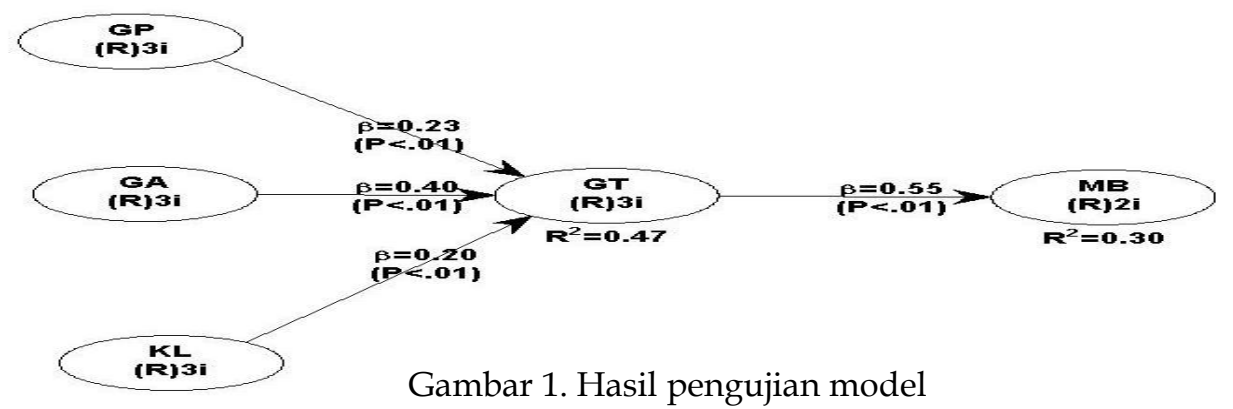

Tabel 3. Hasil pengujian hipotesis

\begin{tabular}{|c|c|c|c|c|}
\hline Hypothesis & Variable correlations & $\begin{array}{c}\text { Path } \\
\text { Coefficient }\end{array}$ & $p$-value & Description \\
\hline H1 & Green Product $\rightarrow$ Green Trust & 0.23 & $<0.01$ & Supported \\
\hline $\mathrm{H} 2$ & Green Advertising $\rightarrow$ Green Trust & 0.40 & $<0.01$ & Supported \\
\hline $\mathrm{H} 3$ & Kepedulian Lingkungan $\rightarrow$ Green Trust & 0.20 & $<0.01$ & Supported \\
\hline $\mathrm{H} 4$ & Green Trust $\rightarrow$ Minat Beli & 0.55 & $<0.01$ & Supported \\
\hline
\end{tabular}

Gambar 1 dan Tabel 3 merepresentasikan bahwa semua hipotesis diterima. Evaluasi Goodness of fit model struktural (inner model) ditunjukkan dengan nilai $R$ square dapat dihitung menggunakan nilai $Q^{2}$ predictive relevance sebagai berikut:

$\mathrm{Q}^{2}=1-\left(1-\mathrm{R}_{1}^{2}\right)\left(1-\mathrm{R}_{2}^{2}\right)$

$\mathrm{Q}^{2}=1-(1-0,47)(1-0,30)=0,629$
Hasil perhitungan diperoleh nilai Q-square $\left(\mathrm{Q}^{2}\right)$ adalah 0,629 , artinya bahwa konstruk yang digunakan dalam model penelitian memiliki relevansi prediksi baik dan layak digunakan.

Green product memiliki nilai tambah dan aman bagi kesehatan. Selain itu, pencantuman eco-label pada kemasan memudahkan konsumen untuk membeda- 
kan produk hijau dengan produk konvensional. Kejelasan informasi yang tercantum pada eco-label akan menambah keyakinan konsumen terhadap kualitas produk hijau (Atkinson et al., 2014; Taufique et al., 2016). Hasil penelitian ini konsisten dengan penelitian Alshura dan Zabadi (2016); Cahyani dan Wardana (2015) bahwa kepercayaan pada produk hijau ditunjukkan dengan tingginya intensitas komsumsi green product karena kualitasnya yang lebih baik. Hal yang penting adalah jika konsumen yang memiliki pengetahuan yang baik tentang lingkungan maka akan cenderung percaya dan menyukai terhadap produk hijau.

Berkaitan dengan green advertising, menunjukkan bahwa green advertising berpengaruh positif signifikan terhadap green trust dengan nilai signifikansi $p$-value $<0,01$. Melalui promosi going green di berbagai media dan tindakan nyata pelestarian lingkungan yang dilakukan pelaku usaha, maka akan menumbuhkan kesadaran konsumen pentingnya melindungi lingkungan dan membuat konsumen makin percaya terhadap produk hijau. Pernyataan pada green advertising mengakibatkan kepercayaan konsumen makin tinggi terhadap green product. Hasil penelitian sejalan dengan penelitian Gunarso dan Kusumawati (2017); Mkik et al. (2017) bahwa iklan yang berwawasan lingkungan dapat membuat konsumen peduli dan percaya bahwa produk telah memberikan dampak positif bagi lingkungan.

Kepedulian lingkungan yang diukur berupa emosi yang dirasakan seseorang terhadap aktivitas yang merusak lingkungan sekitar. Mostafa (2007) mengungkapkan bahwa kepedulian lingkungan yang dimiliki oleh seseorang memiliki dampak signifikan pada sejauh mana individu termotivasi mengubah perilaku untuk meringankan permasalahan lingkungan hidup. Hal ini mengindikasikan makin tinggi kepedulian lingkungan seseorang maka makin tinggi rasa percaya pada produk hijau dan begitu juga sebaliknya. Dapat disimpulkan bahwa kepedulian lingkungan mampu meningkatkan rasa percaya konsumen terhadap kinerja yang diberikan produk hijau. Hasil studi ini diperkuat oleh Aman et al. (2012) yang menyatakan bahwa kepedulian lingkungan berpengaruh signifikan terhadap keyakinan konsumen terhadap nilai tambah yang diberikan produk hijau. Khaola et al. (2014) menegaskan bahwa kepedulian lingkungan merupakan determinan penting dalam mempengaruhi kepercayaan konsumen terhadap produk hijau. Kepedulian lingkungan dapat mendorong konsumen untuk lebih percaya dan lebih menyukai produk hijau, yang akhirnya akan membuat konsumen memiliki preferensi tinggi untuk membeli produk tersebut.

Hubungan antara green trust dan minat beli berpengaruh positif signifikan dengan nilai $p$-value $<0,01$. Makin tinggi rasa percaya konsumen terhadap produk hijau maka kemungkinan minat beli produk hijau juga makin tinggi. Hasil ini memperkuat penelitian sebelumnya yang menyatakan bahwa sikap percaya terhadap produk hijau berpengaruh positif signifikan terhadap minat beli (Aman et al., 2012; Khaola et al., 2014; Sreen et al., 2017; Yadav dan Pathak, 2017). Hasil penelitian ini mengkonfirmasi Theory of Reasoned Action yang menge-mukakan bahwa sikap merupakan prediktor minat yang paling akurat (Ajzen dan Fishbein, 1980). Munculnya rasa percaya yang tinggi terhadap produk hijau akan menumbuhkan minat untuk membeli produk tersebut sehingga akan meningkatkan peluang terjadinya pembelian produk hijau secara aktual.

\section{SIMPULAN}

Hasil penelitian yang telah dilakukan di Kota Malang membuktikan bahwa green product, green advertising, dan kepedulian lingkungan merupakan faktor penting untuk membangun kepercayaan konsumen terhadap produk hijau yang berdampak terhadap peningkatan minat beli. Konsekuensinya, sangat penting bagi perusahaan memproduksi produk ramah lingkungan untuk meningkatkan nilai tambah dan daya saing. Selain itu, upaya meningkatkan pengetahuan tentang produk ramah lingkungan dan kesadaran masyarakat terhadap masalah lingkungan bisa dilakukan dengan kolaborasi antara perusahaan dan pemerintah dengan mengkampayekan isuisu lingkungan dan melakukan edukasi kepada masyarakat sejak dini. 


\section{DAFTAR PUSTAKA}

Ajzen, -I., Fishbein, -M. 1980. Understanding Attitudes and Predicting Social Behavior. Englewood Cliffs, NJ: PrenticeHall. Germany. https://adoc.tips/ajzen -i-fishbein-m-1980-understandingattitudes-and-predicti.html

Albino, -V., Balice,- A., Dangelico, -R.M. 2009. Environmental Strategies and Green Product Development, an Overview on Sustainability-Driven Companies. Business Strategy and the Environment, 8 (2), 83-96. https://doi.org/10.1002/bse.638

Alshura, -M.S, Zabadi, -A.M. 2016. Impact of Brand Trust, Green Brand Awareness, Green Brand Image, and Green Perceived Value on Consumer's Intension to Use Green Products: An Empirical Study of Jordanian Consumers. International Journal of Advanced Research, 4 (2), 1423-1433. http://www.journalijar.com/uploads/ 348_IJAR-8878.pdf

Aman, -A.H., Harun., -A., Hussein, -Z. 2012. The Influence of Environmental Knowledge and Concern on Green Purchase Intention the Role of Attitude as a Mediating Variable. British Journal of Arts and Social Sciences, 7 (11), 145-167. http: //doi.org/10.18415/ijmmu.v6i2.706

Astini, -R. 2016. Implikasi Green Brand, Green Satisfaction dan Green Trust Terhadap Loyalitas Pelanggan (Studi Kasus Pada Konsumen AMDK Galon Merk AQUA di Wilayah Serpong Utara). Jurnal Manajemen, 20 (1), 19-34. http://doi.org/10.24912/jm.v20i1.63

Atkinson, -L, Rosenthal, -S. 2014. Signaling the Green Sell: The Influence of Ecolabel Source, Argument Specificity, and Product Involvement on Consumer Trust. Journal of Advertising, 43 (1), 3345. https:// doi.org/10.1080/00913367. 2013.834803

Batool, -S, Iqbal, -R. 2016. Impact of Green Advertising on Consumer Purchase Behavior. International Interdisciplinary Journal of Scholarly Research, 2 (1), 16 - 22

Cahyani, -N.L.T, Wardana, -I.M. 2017. Peran Green Trust dalam Memediasi Pengaruh Green Product Perception terhadap Green Repurchase Intention. E-Jurnal
Manajemen Unud. 6(6), 2933-2966. https://ojs.unud.ac.id/index.php/Ma najemen/article/view/29808/18924

Chan, -R.Y.K., Lau, -L.B.Y. 2000. Antecedents of Green Purchases: A Survey in China. Journal of Consumer Marketing, 17 (4), 338-357

Chen, -T.B., Chai, -L.T. 2010. Attitude Towards the Environment and Green Products: Consumers' Perspective. Management Science and Engineering, 4 (2), 27-39. http://dx.doi.org/10.3968/j. mse.1913035X20100402.002

Chen, -Y.S. 2011. Green Organizational Identity: Sources and Consequence. Journal of Management Decision, 50 (3), 384-404. https://doi.org/0.30845/ijbss. v9n10p9

Diamantopoulos, -A., Schlegelmilch, -B.B., Sinkovics, -R.R., Bohlen, -G.M. 2003. Can Socio-demographics Still Play a Role in Profiling Green Consumers? A Review of the Evidence and an Empirical Investigation. Journal of Business Research, 56, 465-480

D'Souza, -C., Taghian, -M., Lamb, -P. 2006. An Empirical Study on The Influence of Environmental Labels on Consumers. Corporate Communications: An International Journal 11(2), 162-173. https:/ / doi. org/10.1016/S0148-2963(01)00241-7

Ferdinand, -A.T. 2006. Metode Penelitian Manajemen. Badan Penerbit Universitas Diponegoro. Semarang

Gbadamosi, -A. 2016. Handbook of Research on Consumerism and Buying Behavior in Developing Nations. IGI Global. United States of America

Grewal, -D dan Levy, -M. 2010. Marketing $2^{\text {nd }}$ Edition. McGraw Hill. New York

Gunarso, -A., Kusumawati, -A. 2017. Pengaruh Green Advertising, Eco Brand, dan Green Trust terhadap Keputusan Pembelian. Jurnal Adminis-trasi Bisnis, 49 (1), 169 - 178. http:/ / administrasibisnis.stu dentjournal.ub.ac.id/index.php/jab/ar ticle/view/1908/2291

Halim, -J., Kempa, -S. 2016. Pengaruh Green Perceived Value, Green Perceived Risk, Green Trust, dan Perceived Value Terhadap Green Purchase Intention Produk AC Low Watt di Surabaya. Agora, 4 (1), 404-413. http:/ / publication 
.petra.ac.id/index.php/manajemenbisnis/article/view/6512/5928

Hassan, -R., Valenzuela, -F. 2016. Customer Perception of Green Advertising in The Context of Eco-Friendly FMCGs. Contemporary Management Research, 12 (2), 169 - 182. https:/ / doi.org/10.7903/ cmr.14796

Hennessy, -M. 2012. Advancing Reasoned Action Theory. The American Academy of Political and Social Science, University of Pennsylvania. Philadelphia

Ihemezie, -E.J., Ukwuaba, -I.C., Nnaji, -A.N. 2018. Impact of 'Green' Product Label Standards on Consumer Behavior: A Systematic Review Analysis. International Journal of Academic Research in Business and Social Sciences, 8 (9), $666-684$.

Irfan, -F., Khiriyah, -S. 2013. Faktor - Faktor yang Mempengaruhi Niat Konsumen untuk Membeli Produk Hijau. Jurnal Fokus Manajerial 12 (1), 12-22. https:/ /jurnal.uns.ac.id/fokus-manaje rial/article/viewFile/1948/1820

Jørgensen, -R.B., Moen, -Ø. 2015. Eco Labelling from the Consumer Perspective: A Case Study of Indoor Paint Products. Journal of Research for Consumer, 27, 1-25. http://jrconsumers. com/Academic_Articles/issue_27/Issue27AcademicArticle-Oystein1-25.pdf

Junaedi, M. F. S. 2008. Pengaruh Gender Sebagai Pemoderasi Pengembangan Model Perilaku Konsumen Hijau di Indonesia. Jurnal Kinerja Bisnis dan Ekonomi, 12 (1), 17-37. https:/ / doi.org/ 10.24002/kinerja.v12i1.1388

Kabadayi, -E.T., Dursum, -I., Alan, -A.K., Tuger, -A.T. 2015. Green Purchase Intention of Young Turkish Consumers: Effects of Consumer Guilt, SelfMonitoring and Perceived Consumer Effectiveness. Procedia - Social and Behavioral Sciences, 207, 165-174. https:/ / doi.org/10.1016/j.sbspro.2015. 10.167

Kalafatis, -S.P., Pollard, -M., East, -R., Tsogas, -M.H. 1999. Green Marketing and Ajzen's Theory of Planned Behaviour: A Cross-market Examination. Journal of Consumer Marketing, 16 (5), 441-460. https://ojs.unud.ac.id/index.php/Manajem en/article/view/11583 https://doi.org/10.1108/073637699102 89550

Khaola, -P.P., Potiane, -B., dan Mokhethi, M. 2014. Environmental Concern, Attitude Towards Green Products and Green Purchase Intentions of Consumers in Lesotho. Ethiopian Journal of Environmental Studies \& Management, 7 (4), 361-370

Ling, -K.C., Daud, -D., Piew, -T.H., Keoy, K.H., Hassan, -P. 2011. Perceive Risk, Perceived Technology, Online Trust for the Online Purchase Intention in Malaysia. International Journal of Business and Management, 6 (6), 167-182. https://doi.org/10.5539/ijbm.v6n6p16 7

Mei, -O.J., Kwek, -C.L., Tan, -H.P. 2012. The Antecedents of Green Purchase Intention among Malaysian Consumers. Journal Asian Social Science, 8(13), 248 263. https://doi.org/10.4314/ejesm.v7 i4.3

Miranti, -S. 2012. Pengaruh Perbedaan Jenis Kelamin terhadap Perilaku Pembelian Produk Ramah Lingkungan di Jakarta. University of Indonesia Library Press. Depok

Mkik, -S., Khouilid, -M., Aomari, -A. 2017. Green Advertising and Environmentally Consumption: The Level of Awareness and Moroccan Costumer's Perception. Journal of Business and Management, 19 (8), 1 - 11. https:/ / doi.org/10.9790/ 487X-1908030111

Muslim, -E., Indriani, -D.R. 2014. Analisis Pengaruh Eco-Label terhadap Kesadaran Konsumen untuk Membeli Green Product. Manajemen Teknologi, 13 (1), 66-80

Nguyen, -L.Q., Du, -Q. 2010. Effectiveness of Student's Choice in Ecological Food. Umea School of Business. Swedia

Poeradisastra, -F. 2011. Prospek dan Pengembangan Industri Minuman Ringan di Indonesia. Food Review Indonesia Edisi Februari

Priyantika, -I.G.., Wardana, -I.M. 2015. Pengaruh Green Advertising dan Green Claim pada Niat Membeli Ulang Konsumen Green Product. E-Jurnal Manajemen Unud, 4 (5), 1186-1195.

Rasaputra, -C.J., Choon-Yin, -S. 2015. An Investigation on Consumer Purchasing 
Decision of Green Products: The Case of Singapore. International journal of Advances in Management and Economics, 4 (2), 87 - $94 . \quad$ https://www.manage mentjournal.info/index.php/IJAME/a rticle/view/419/362

Richards, -L. 2013. Examining Green Advertising and Its Impact on Consumer Skepticism and Purchasing Patterns. The Elon Journal of Undergradu ate Research in Communica-tions, 4 (2), 78-90. http://www.inquiriesjournal. com/articles/825/view

Ruanguttamanun, -C. 2014. The Use of Appeals in Green Printed Advertisements: A Case of Product Orientation and Organizational Image Orientation Ads. World Academy of Science, Engineering and Technology. International Journal of Humanities and Social Sciences, 8 (9), 2988-2993. https:/ / doi.org/10.52 81/zenodo.1096049

Said, -A.M., Ahmadun, -F., Paim, L., dan Masud, J. 2003. Environmental Concerns, Knowledge and Practices Gap Among Malaysian Teachers. International Journal of Sustainability in Higher Education, 4 (4), 305-313. https://doi. org/10.1108/14676370310497534

Sdrolia, -E., Zarotiadis, -G. 2019. A Comprehensive Review for Green Product Term: From Definition to Evaluation. Journal of Economic Surveys, 33 (1), 150-178. https:// doi.org/10.1111 /joes.12268

Seyrek, -I.H., Gul, -M. 2017. Factors Affecting Green Purchasing Behavior: A Study of Turkish Consumers. International Journal of Academic Research in Business and Social Sciences, 7 (1), 306-319. https: //doi.org/10.6007/IJARBSS/v7-i1/ 2607

Simamora, -B. 2004. Panduan Riset Perilaku Konsumen. PT Gramedia Pustaka Utama. Jakarta

Sreen, -N., Purbey, -S., Sadarangan -P. 2017. Impact of Culture, Behavior and Gender on Green Purchase Intention. Journal of Retailing and Consumer Services, 41, 177-189. https://doi.org/ 10.1016/j.jretconser.2017.12.002
Suki, -N.M. 2013. Green Awareness Effects on Consumer's Purchasing Decision: Some Insights from Malaysia. Internatio nal Journal of Asia Pacific Studies, 9 (2), 49-63. https://ijaps.usm.my/wp-conte nt/uploads/2013/07/Art3.pdf

Taufique, -K,M.R., Vocino, A. Polonsky, -M.J. 2016. The Influence of Eco-label knowledge and Trust on Pro-Environ mental Consumer Behavior in an Emerging Market. Journal of Strategic Marketing, 25 (7), 511-529. https:/ / doi. org/10.1080/0965254X.2016.1240219

Testa, -F., Iraldo, -F., Vaccari, -A., Ferrari, -E. 2013. Why Eco-labels can be Effective Marketing Tools: Evidence from a Study on Italian Consumers. Journal of Business Strategy and the Environment 24(4): 252-265. https:// doi.org/10.1002 /bse.1821

Utami, -R.D., Gunarsih, -T., Aryanti, -T. 2014. Pengaruh Pengetahuan, Kepedulian dan Sikap pada Lingkungan terhadap Minat Pembelian Produk Hijau. Media Trend 9(2): 151-16. https://pdfs.seman ticscholar.org/031b/4f4e70876f26ed1f9 2b2623b9eb9a7f7f229.pdf

Widmer, -P., Frick, H. 2007. Hak Konsumen dan Ekolabel: Informasi Konsumen Tentang Produk yang Ramah Lingkungan dan Kebutuhan Atas Ekolabel. Kanisius. Yogyakarta

Wu, -S.I., Chen, -Y.J. 2014. The Impact of Green Marketing and Perceived Innovation on Purchase Intention for Green Products. International Journal of Marketing Studies, 6 (5), 81-100. https:/ / doi.org/10.5539/ijms.v6n5p81

Zhou, -M. 2013. A Multidimensional Analysis of Public Environmental Concern in Canada. Canadian Review of Sociology, 50 (4), 453-481. https://doi. org/10.1111/cars.12028

Yadav, -R, Pathak, -G.S. 2017. Determinants of Consumers Green Purchase Behavior in a Developing Nation: Applying and Extending the Theory of Planned Behavior. Ecological Economics, 134, 114-122. https:// doi.org/10.1016/j. ecolecon.2016.12.019 